\title{
Ambiances
}

anbiances Environnement sensible, architecture et espace urbain Varia | 2013

\section{Luminous atmospheres}

Energy politics, climate technologies, and cosiness in Denmark

Ambiances lumineuses - Politique de l'énergie, technologies climatiques et intimité domestique au Danemark

\section{Mikkel Bille}

\section{CpenEdition}

\section{Journals}

\section{Electronic version}

URL: http://journals.openedition.org/ambiances/376

DOI: $10.4000 / a m b i a n c e s .376$

ISSN: 2266-839X

Publisher:

Direction Générale des Patrimoines - DAPA - MCC, UMR 1563 - Ambiances Architectures Urbanités (AAU)

\section{Electronic reference}

Mikkel Bille, "Luminous atmospheres », Ambiances [Online], Varia, Online since 20 September 2013, connection on 30 April 2019. URL : http://journals.openedition.org/ambiances/376 ; DOI : 10.4000/ ambiances.376

This text was automatically generated on 30 April 2019.

\section{(c) (i) (9)}

Ambiances is licensed under a Creative Commons Attribution-NonCommercial-NoDerivatives 4.0 International License. 


\title{
Luminous atmospheres
}

\author{
Energy politics, climate technologies, and cosiness in Denmark \\ Ambiances lumineuses - Politique de l'énergie, technologies climatiques et \\ intimité domestique au Danemark
}

Mikkel Bille

\section{Introduction}

1 Atmospheres are a strange sort of stuff. First of all, the term has two different meanings by both connoting the atmosphere around the earth - that is, a meteorological phenomenon - as well as the personal, spatial experience of engaging material things (Hasse, 2012, p. 19) ${ }^{1}$. In this latter understanding, both the ontological and epistemic status of atmospheres is somewhat vague (Böhme, 1995, p. 22 ; Rauh, 2012, p. 190-197). On the one hand people feel them, are affected by them, and may seek to retain them. On the other hand they cannot be touched, measured or seen, and people may never fully hold or even grasp their existence (Böhme, 1995; Zumthor, 2006). Over the last couple of decades scholars have explored this ambiguous nature of atmosphere (Anderson, 2009; Böhme, 2001; Goetz \& Graupner, 2007; Stewart, 2011). However, rarely do scholars explore the political and moralising premises and potentials of atmospheres (but cf. Hasse, 2012; Balina \& Evgeny, 2009; Bisgaard \& Friberg, 2006). Peter Sloterdijk highlights such politics of atmospheres, when he argues that,

For present-day cultures the question of survival has become a question of the way in which they are reproduced as atmospheric communities. Even physical atmospheres have passed to the stage of their technical producibility. The future era will be climate-technical, and as such technologically oriented. It will be increasingly seen that societies are artificial from the ground up. The air that, together and separately, we breathe can no longer be presupposed. Everything must be produced technically, and the metaphorical atmosphere as much as the physical atmosphere. Politics will become a department of climate techniques. (2011, p. 245).

2 Following this, and with the development of climate technologies, it has become increasingly clear that both understandings of the term are indeed central to the way 
people perceive and act in the world, and will do so in the future. Climate technologies are developed to reduce a particular kind of impact of human practices on the environment. At the same time these technologies are changing the way people perceive themselves, each other, and the material world, through their impact on the experienced atmospheres of a place. Like many other technologies, these new things thus help people gain access to the world, perceive new aspects, and help shape what counts as real (Ihde, 1990, p. 48). Recent literature on materiality has focused on the role of objects in shaping morality (Verbeek, 2011), and although only explored in brevity here, I wish to suggest that despite the intangible and ambiguous nature of atmospheres, they also take part in mediating such political and moral regimes.

In this article I want to investigate one such political aspect of atmospheres by exploring why the implementation of energy saving lighting technologies are generally contested in Denmark. While Sloterdijk may be correct in stating that atmospheres are taking centre stage of politics, it is also clear that there is not necessarily compliance from all parties involved in this era of climate politics. People may resist; they may not accept the facts that other people adhere to; people may be utterly ignorant to such facts, or indifferent to the moral regimes forced upon them by them (High \& Mair, 2012; Proctor \& Schiebinger, 2008). Technologies may not work as well as planned or not work together with other technologies; or, as in the case with the energy saving light bulb, people may not be satisfied with the very materiality of such new technologies. Light matters, but small differences in nuance may matter even more.

4 As an anthropologist I am inclined to highlight the importance of taking cultural aspects of atmosphere more seriously; what are the cultural premises and social effects of atmospheres; what meanings are associated with the technology; what issues of gender, power, prestige, tradition, or public/private distinctions are at stake? But at the same time, it is also clear that exploring atmospheres also offers a particular lens for understanding cultural aspects of the orchestration of spaces and affects. In this case, understanding the adaptation of new lighting technologies, perceptions of pollution, and what a social event feels and ought to feel and look like. Century long lighting traditions centred on the incandescent light bulb are not just discarded overnight. Such technologies have become embedded in social life through habits and norms about the way people interact (Bille \& Sørensen, 2007; Garnert, 1993, 1994). The topic of this paper is then, why new technologies are resisted and how light unfolds in atmospheric orchestration of social life in Denmark.

\section{Ethical consumption and new technologies}

In the past three decades we have seen the emergence of ethical consumption as a largescale economic potential (Carrier \& Luetchford, 2012; Lyon \& Moberg, 2010). When it comes to fair-trade or organic food, the ethical aspects of consumption are very much up front: paying a fair amount of money to the third world worker, and making sure the animals have had a minimum of rights before we consume them. People may choose not to buy these products, but most often this is a decision based on price or habits, and not necessarily the qualities of the goods.

However, when it comes to buying energy saving light bulbs, the matter is very different, at least in Denmark. The incandescent light bulb is by September 2012 officially no longer 
in production in EU. Politicians, lobbyists and NGOs want to decide what people will spend their money on for the common good of the planet. This follows a commonly used practice that when people do not themselves adopt a new technology, banning the old one is a powerful way to change habits, which then leads to rapid improvement of the new technology. For the new lighting technologies it is a bit different since the only technology that was sufficiently developed and available to common households at the initiation of the ban was the compact fluorescent light bulb (CFL), which many scholars and engineers already at that point critiqued for its poor qualities. However, the CFL bulb can also be seen as an intermediary technology, since hopes are, and were, high for the LED bulbs as the future means of artificial lighting. While the LED low energy consumption is promising, prices are still high and people are not yet used to the new possibilities of illuminating the homes that they offer. In return, many Danes have hoarded the incandescent light bulbs while scorning the CFL bulbs, and remain only potentially positive about the possibilities the LED may offer. Why would anyone be against saving the planet by saving energy and money on their electrical bill?

7 The answers are of course manifold. One obvious answer is the technological fact that the light quality of the CFL bulb is different as it has higher colour temperature and lower colour reproduction than the incandescent bulb. It may be minor nuances, but it is noticeable, even to the point where some scholars argue that it has an effect on people's sleep patterns (Czeisler, 2013). From an economic perspective the initial cost of the bulb is also higher than the incandescent, and rather than just throwing the fused bulb in the dustbin, people have to deliver them as special waste due to the mercury content. The fear is that this will not happen with great pollution as a result. The bulb also emits less heat, which in wintertime has to be compensated for by other means.

Yet, a look around the globe also shows that the CFL bulb's lighting qualities may be appreciated differently. Further south in Europe, in the Middle East and Africa there is for instance a preference for stronger direct white lights compared to dimmed and reddish glow further north, such as in Scandinavia. This observation is at times justified by what we may call the 'geographical argument' in which people's lighting practices mimic the course of the sun. Short transition to night around equator is mimicked by strong interior light, while long transitions further north make room for more reddish glow. Lightscapes have thus in many ways become perceptual benchmarks of normality to the extent where one can talk about light cultures. The notion of a particular 'Nordic Lighting' (Sørensen \& Haug, 2012) has become popular in Scandinavia, claiming that there is a particular natural light in this region, which guides the light practices. Nordic Lighting can be seen as part of an 'authentic Nordic' movement binding the Scandinavian countries together as a distinct cultural group, and includes the 'Nordic Cuisine', 'Nordic School', 'Nordic Design', and 'Nordic welfare-model'. It is a shared sense of cultural sameness.

9 When it comes to light, and the sense of atmosphere it creates, it is a tempting argument, which, however, is also somehow flawed. Copenhagen, Glasgow, and Moscow are approximately on the same latitude, but people have very different lighting practices. There is also an enormous variation in light setting from the mountains of Northern Sweden to the fjords of Norway, and to the hills in Denmark. It would be more correct to state that there is a particular appreciation of light in Scandinavia, rather than it is the very nature of the light. Also, fashion may influence more strongly than the natural light, where the brown colours of the 1970s post oil crisis interior design, have now been 
replaced by a strong focus on natural light and whiteness, perhaps under the influence of popular Danish architects such as Henning Larsen - the 'Master of light'.

The point is that this appreciation of light shows that 'good' lighting quality should not be taken for granted as that which comes closest to daylight, such as the incandescent light bulb, but as that which makes most cultural sense. So clearly other issues are at stake with the contestation over new lighting technologies than simply a matter of any objective notion of 'poor' light quality or geographical determinism. One such issue that I want to explore here has to do with questions about the cultural perceptions of cleanliness, either aesthetically or bacteriologically, and by extension the role of light in shaping the feeling of a place.

Light is thoroughly embedded in social practices, sensations of space, and notions of security, spirituality, and hominess that may be beyond words and meaning, and simply rely on sensuous immediacy and presence (Bille \& Sørensen, 2007; Bille, in press; Sørensen \& Bille, 2007). Electrical light, for instance, has become so common that many people often do not notice it, and when they do notice it, it is because something is somehow wrong: not working, too bright, too dim, too much glare, too poor quality, etc. From this position, one can perhaps suggest that the best lighting design is unnoticeable, because it captures the atmosphere that people are accustomed to, expect, or anticipate. Merleau-Ponty's famous dictum that we do not see light, but see in light, seems to hold ground (1964, p. 178). Yet, the new lighting technology has also made people in Denmark increasingly aware of light as an atmospheric co-producer, and many are frustrated over the lacking ability of the new technology to fulfil the social functions they need it for, and thus whatever they understand as good lightscapes.

More than simply an issue of everyday aesthetics, and poor lighting technologies, lighting practices also ties in closely with notions of morality, beyond the close metaphorical relationship between religion, truth and light (Blumenberg, 1993; Kapstein, 2004). Just prior to the 2009 international climate convention COP15 in Copenhagen, Denmark, Thor Pedersen, a prominent member of the ruling party and former Finance Minister, proclaimed that the climate debate and initiatives to reduce $\mathrm{CO}_{2}$ emission was getting out of hand, and interfered with people's personal freedom. He remarked that he enjoys coming home to his empty house and see lights glowing from all his windows. The remark was met with moral indignation of wasting energy, and was used politically to question the government's intentions and abilities to promote Denmark as the forefront of environmental sustainability, contained in the Danish promotional slogan 'State of Green'.

Yet, the remarks were also backed up by many people, who had become sceptical about the moral duty of reducing $\mathrm{CO}_{2}$ emission that had emerged in Denmark. It was not scepticism about the debate over the 'facts' of global warming, but of the way small details in everyday life was to be minutely evaluated by its emission of $\mathrm{CO}_{2}$, and thereby enforcing moral judgments. Thor Pedersen's protest was about atmosphere in every sense of the word: it was about the earth's atmosphere, because the energy consumption for lighting is a large percentage of the total $\mathrm{CO}_{2}$ emission. It was also about a much more experience-near atmosphere of what the home ought to look and feel like, for it to be a proper welcoming home. Thus, in order to understand the resistance to energy saving technologies and behaviour that would reduce harm to one kind of atmosphere - the earth's - we need to consider the impact of these technologies and lighting behaviour on the atmosphere that people opt for in their everyday life. The impact is one that inserts 
politics and morality into the consumption choices that people make when it comes to light.

\section{Cosy atmospheres}

14 As mentioned above, an atmosphere is an elusive multi-sensuous in-between that has to be felt as a co-presence and immediacy of subject and object (Böhme, 1995, 2006). An atmosphere is never stable or objective. Rather, it is a genre of socio-material interaction that is activated and aims at - or has its premises in - cultural concepts, interpretations, and anticipations. Thus, opting for particular atmospheres have cultural premises that among other things make subtle use of light to shape for instance cosiness, work productivity, or sense of security.

15 To explore this impact of new technologies, I now turn to the orchestration of light in Danish homes and social life, and the central notion of hygge, generally translated into cosiness (see Linnet, 2011). Hygge is often described and idealised as a particular feeling or way of being together; a feeling of informality, relaxation, and cosiness that rules much social behaviour in Denmark and both valorises situations and structures spaces (Winther, 2005, 2006; Gram-Hanssen, 2008). The term is used in everyday language to describe a wide range of social events, interactions and spatial settings, from the café, the modern minimalistic home, to an idyllic farmhouse, as well as appears in various grammatical forms of verbs, adjectives and nouns. Many Danes claim that the term is not easily translatable to other languages, although in Norwegian, German and Dutch terms exist that cover much the same kind of cosy, homey, informal, and relaxed atmosphere (Linnet, 2011, p.2). It is an atmosphere shaped through the material infrastructure, whether one is sitting alone, tucked in under a blanket with a cup of tea, in a restaurant with a partner or friend, or at a larger social event.

While there are of course many exceptions and variations over the structure, content and orchestration of this cosy atmosphere - its mental states and material infrastructures light has a prominent role in shaping it. This generally implies dimmed lighting dispersed across the rooms to shape smaller spaces within spaces, often (but not always) assisted by candlelight. A common term used for such lightscape is hyggelys or cosy-light. My informants often state that they light candles or dim the light to subconsciously remind people and themselves to relax and stress down ${ }^{2}$. A lit candle, or the dimmed dispersed light, is a welcoming sign both in public and private spaces as an invitation to cosiness even if it may imply being forced into norm-governed behaviour. The dimmed light announces that what is sensed - and what should be sensed - is a socially relaxed, informal atmosphere. That said, of course the preparation and maintenance of cosiness may indeed be stressful itself for the guests, hosts or family, as expectation may be high to make sure that everything is in place.

It is a highly performative orchestration of space where lights are dimmed, turned off, curtains pulled, and candles replaced as time passes ( $c f$. Garvey, 2005; Stender, 2006). Light, in this sense, becomes a practice and a process that affects people's moods. People turn on lights in rooms where they are not present to shape a sense that they are not alone; a woman may turn on the lights in the dark room where the husband is watching television or playing computer, to signal social life rather than solitude; and people dim the light as evening progresses to shape intimacy. The cosy atmosphere is in constant creation in both interpersonal and material ways. It involves a particular care for visual 
comfort in terms of glow, shadows and visually convoluted spaces. People may not notice that they are doing this, but when asked, all informants are able to reflect upon their actions and what kind of atmosphere they opt for. Informants are very much aware that light shapes spaces and moods, but this reflection mostly emerge when asked directly.

\section{Dealing with an unsatisfactory technology}

18 By most estimates $20-25 \%$ of the energy in private homes is spent on light ${ }^{3}$. This, of course, also means that a large amount of $\mathrm{CO}_{2}$ emission is caused by the use of light. With the implementation of EU regulations on energy saving light sources, the last incandescent light bulbs have now been phased out. Technologies such as halogen bulbs and LED exist, but the CFL bulbs have been widespread for reasonable prices, and the one that is commonly understood as the energy saving light bulb in Denmark. The more expensive and better quality CFL bulbs are rarely the ones being sold in supermarkets and DIY-shops.

19 Some of my informants did emphasise that they use the energy saving light bulb because it lowers the electrical bill, but very few have been satisfied with the overall experience. While lauded for its energy saving capabilities, many people in Denmark have over the past decade scorned the low colour reproduction ( $r a$ 80-85) and/or high colour temperature ( $>2900$ Kelvin). Visually such qualities change the domestic infrastructure into what informants call 'dull', grey surfaces, compared to the reddish glow from the incandescent bulb (2700 Kelvin) and colour reproduction ( $r a 99$ ) more similar to daylight.

Although the technology is rapidly improving, the average CFL bulbs sold in supermarkets have several problems when it comes to shaping hygge. The bulbs have slow starting capacity, may not fit into the lampshades, have a more narrow direction of light, and are most often unable to work with the existing switches for dimming light; a seemingly indispensable practice in a Danish domestic context. And besides, the very shape of them, confronts any habitual sense of design. With the new technology, the 'warm', reddish, and subdued glow from the incandescent light bulb is replaced by a 'colder', 'clearer', some say 'bluish' light. In that sense, lighting technologies are ecstatic (Böhme, 1995, p. 155-176) in that the source of light - be it the sun, the lamp or a reflecting surface - can transcend its own tangibility and extend its particular 'being' onto the world and shape the way people perceive their environment. The effect is that while many Danes have unwillingly had to adopt the new technology, many people also hoard the incandescent light bulbs, or specifically use the bulbs they have left for selected spots in the house where they particularly seek cosy light, such as the living room. Shaping a cosy atmosphere, thus, wins over environmental ethics.

\section{Living with pollution}

21 While the Member of Parliament Thor Pedersen's questioning of the moral imposition of environmental awareness only dealt with electrical light and energy consumption, more is however at stake in the debates about the earth's atmosphere and environment when it comes to the use of candlelight. Many Danes have an excessive use of candlelight, called 'living light'. Candles are lit at broad daylight at lunch tables and even cafés to announce the cosy moment. It is not so much a matter of visually being able to see, as it is the 
(subconscious) announcement of the potential for a 'gathering' of moods, materiality and social life into a cosy atmosphere. The excessive use of candle light amounts to the commonly held idea that Danes have the highest use of candlelight per capita in the world - to much distress for people with chronic obstructive pulmonary disease. At Christmas time the average use of candlelight triples. In autumn and winter, a recent survey showed that 28 per cent light candles every day, with 31 per cent lighting more than 5 candles at a time ${ }^{4}$.

It is not only candlelight that the Danes make excessive use of. There is also an intensive use of fireplaces. According to some statistics, the use of fireplaces in Denmark contributes to more particle emission on the streets than traffic ${ }^{5}$. One of my informants explained that during winter she would use the fireplace pretty much every day, despite the fact that the house has a new natural gas heating system. Whether in the fireplace or with the candlelight, the flickering flame shapes cosiness and a place of gathering: the smell, the sound, the direct warmth, and the subdued and moving light shapes a homey, cosy atmosphere. It may be that light brings (biological) life, but it is with a love for shadows and the dimmed light that many Danes live their social life - even if polluting the environment is the effect.

Hence, from my interviews about domestic lighting and new technologies, there appears to be many connections between pollution and shaping atmospheres through light (Carter, 2007; Garnert, 1993, 1994; Shove, 2003). In the same way as the question of what is to be considered the proper visual orchestration of space, so too is what is considered dirty embedded in cultural understandings of 'normality'. Light has long been used both as a social hygienic tool to lower crime and a medical tool to increase health. The social history of hygiene over the last 150 years has shown that the use of a guilt-inducing rationale for increased hygiene has required a reconfiguration of the senses, where dirt is to be considered simultaneously a moral and a physical issue (Campkin \& Cox, 2007, p. 2; Schivelbusch, 1988; Schmidt \& Kristensen, 1986). Like atmospheres, so too does dirt slip 'easily between concept, matter, experience and metaphor' (Campkin \& Cox, 2007, p. 1).

However, to my informants, such categories as 'dirty' and 'clean' are not necessarily opposites, or a distinction between good/clean and bad/dirty. To them there is a fine balance between cleanliness and what is called 'sterile'. Some informants tell stories of how they vacuum the house before guests arrive and clean up their houses. This is not necessarily because it is really dirty, but just to do it and feel that the room is clean, thus ascribing both to a hygienic regime as well as a moral discourse of cleanliness imposed on the host. If the moral duty to have a clean home is not achieved, then others, such, as my informant Anne, describes how dimmed light:

[...] does not reveal details. Things are allowed to stand a bit in the shadow [...] Borders dissolve. It may sound strange. But I think that, if you put fluorescent light in here, I would be able to see all the dust balls on the floor. Those things disappear when you have the cosy-light. (Islands Brygge, February $8^{\text {th }}$ 2012)

Light in other words is part of producing an image of a clean home. However, there is a balance between the clean and the sterile. The sterile, both as aesthetic expression and bacteriological reality, does not fit in easily with the orchestration of domestic atmospheres. If the home is too clean, too neat, too new, too planned, too designed, it would resemble a public office or hospital - not a home. In that respect, I would argue that the opposite of hygge or cosiness - at least in a material perspective - is not necessarily 'the uncanny', or 'the un-cosy', but rather the 'sterile'. The sterile is a particular kind of 
sensuous encounter that both deals with regimes of knowledge about bacterial absence, as well as the very sensuous encounter with aesthetical and bacterial absences. The sterile allows for surfaces to step forward as surfaces containing the absent, and this is easily interpreted as a lack of personal touch on interior design and by extension lack of personality.

If dirt is 'matter out of place', as Mary Douglas (1966, p. 44) famously argued, the problem of pollution as a by-product of lighting traditions becomes more ambiguous. What in one regime of knowledge is understood as dirty - such as particle pollution from fireplaces is in another regime, a product of cosy lighting that links to cultural norms and identity among Danes. Particle pollution, in other words, may both be negatively viewed as dirt and positively viewed as a multi-sensuous co-producer of cosy atmospheres, even by the same individual. The smell of the soot, the slightly heavy air, and the aesthetically unsterile expression of the warm glow from the subdued light, flickering flames and shadows that orchestrates the intimacy of the cosy atmosphere, shapes a space that does not look sterile, commercialised, or depersonalised, but rather, gives a cosy, intimate, and personal touch to a home or space. Despite my informants' diverse ways of inhabiting the flats and houses, and amounts of light used, a cosy home is not 'perfect'. It is not something you buy from a shop, but something that is made, is personal, and just a bit not too clean. Thus, what is dirty in one bacterial register of knowledge is needed in an atmospheric register of experience. The home needs a bit of what would be considered 'matter out of place' in a bacteriological sense, to avoid the sterile, and thereby not being cosy.

It is in this distinction between cultural perceptions of dirt and the sterile that the ecstatic qualities of light that the CFL bulb offers, is hitting a nerve. The ecstasy of the bulbs makes things look 'lifeless' and 'sterile' to the informants. Their use of the term 'sterile' may be somewhat metaphorical - more denoting an aesthetic expression, rather than any measurement of bacteria - but nonetheless, it is a minute difference in light setting that challenges the cosy atmosphere.

\section{Summation}

The point of the above exploration into the relationship between atmospheres and new technologies, is that understanding the appreciation of specific material qualities of light, the ecstasies of the bulb's colour reproduction and temperature, the patina and multisensuality of orchestrating lightscapes through the shadows, the flickering flames, and the glow from the subdued lighting, is at the heart of understanding the contestation against adopting a new technology. What would appear to be a moral good - saving tons of $\mathrm{CO}_{2}$ release into the earth's atmosphere by simply switching to the energy saving light bulb - is contested by the lacking ability of a technology to expose the visual world in a way that does not leave a 'sterile' impression (in whatever way that sterility is socially evaluated and continuously rethought). While the luminous aspects of atmospheres have become politically embedded for the greater good of the earth's atmosphere, it does, then, not mean that people easily adopt such politics. People's insistence on the specific materiality of cosy-light makes the cosy atmosphere a political issue. The incandescent light bulb is now phased out, but pressure is starting to be raised also on banning candlelight and wood stoves because of the pollution they emit. Atmospheres both as meteorological and experience are thoroughly embedded in politics. 
could ironically propose that with the new lighting technology, people now see the light, but perhaps the best light is what people don't see; what they don't notice is there, because it fits with atmospheric norms, and doesn't stand out as light, as such, but simply integral part of the atmosphere. Between the intimate, personal experience of cosy atmosphere, and the distant atmospheric impact of $\mathrm{CO}_{2}$ emission and particle pollution, environmental ethics comes in second place. In that sense, as Sloterdijk noted, the future is atmospheric.

\section{BIBLIOGRAPHY}

Anderson, Ben. 2009. Affective atmospheres. Emotion, Space and Society. vol. 2, n 2, p. 77-81.

Balina, Marina \& Evgeny Dobrenko. 2009. Petrified Utopia: Happiness Soviet Style. London: Anthem

Press. 334 pages.

Bille, Mikkel. In press. Verdens uafklarethed. Tidsskriftet Antropologi. vol. 67.

Bille, Mikkel. 2012. Energy saving Technologies and the Battle of Atmosphere. In: Thibaud, JeanPaul \& Siret, Daniel (eds.). Ambiances in action/ambiances en acte(s): Proceedings of the $2^{\text {nd }}$ international congress on Ambiances. Montreal. p. 135-140.

Bille, Mikkel \& Sørensen, Tim F. 2007. An Anthropology of Luminosity: The Agency of Light. Journal of Material Culture. vol. 12, n 3, p. 263-284.

Bisgaard, Ulrik \& Friberg, Carsten. 2006. Det cestetiskes aktualitet. København: Multivers. 272 pages. Blumenberg, Hans. 1993. Light as a Metaphor for Truth: At the Preliminary Stage of Philosophical Concept Formation. In: David M. Levin (ed.) Modernity and the Hegemony of Vision. Berkeley, University of California Press. p. 30-62.

Böhme, Gernot. 1995. Atmosphäre: Essays zur neuen Ästhetik. Frankfurt am Main: Suhrkamp. 204 pages.

Böhme, Gernot. 2001. Aisthetik: Vorlesungen über Ästhetik als allgemeine Wahrnehmungslehre. München: W. Fink. 199 pages.

Böhme, Gernot. 2006. Architektur und Atmosphäre. München: Wilhelm Fink GmbH. 182 pages.

Campkin, Ben \& Cox, Rosie (eds.). 2007. Dirt: New Geographies of Cleanliness and Contamination. London: I.B.Taurus. 262 pages.

Carrier, James G. \& Luetchford, Peter G. (eds.). 2012. Ethical Consumption: Social Value and Economic Practice. Oxford: Berghan. 246 pages.

Carter, Simon. 2007. Rise and Shine: Sunlight, Technology and Health. Oxford: Berg. 224 pages.

Czeisler, Charles A. 2013. Perspective: Casting Light on sleep deficiency. Nature 497, S13 (23 May 2013).

Douglas, Mary. 1966. Purity and Danger: an Analysis of Concepts of Pollution and Taboo. London: Routledge \& K. Paul. 272 pages. 
Garnert, Jan. 1993. Anden i lampan: etnologiska perspektiv paljus och mörker. Stockholm: Carlsson. 307 pages.

Garnert, Jan. 1994. Seize the Day: Ethnological Perspectives on Light and Darkness. Ethnologia Scandinavica. vol. 24, p. 38-59.

Garvey, Pauline. 2005. Domestic Boundaries: Privacy, Visibility and the Norwegian Window. Journal of Material Culture. vol. 10, n², p. 157-176.

Goetz, Rainer \& Graupner, Stefan (eds.). 2007. Atmosphäre(n), Interdisziplinäre Annährungen an einen unscharfen Begriff. München: Kopaed. 311 pages.

Gram-Hanssen, Kirsten. 2008. Energy in Homes: An Historical Approach to Understanding New Routines. In: Mogens Rüdiger (ed.). The Culture of Energy. Newcastle: Cambridge Scholars Press. p. 180-199.

Hasse, Jürgen. 2012. Atmosphären der Stadt. Aufgespürte Räume. Berlin: Jovis. 192 pages.

High, Casey, Kelly, Ann H. \& Mair, Jonathan (eds.). 2012. The anthropology of ignorance: An Ethnographic Approach. New York: Palgrave Macmillian. 230 pages.

Ihde, Don. 1990. Technology and the Lifeworld. Bloomington: Indiana University Press. 226 pages.

Kapstein, Matthew T. (ed.). 2004. The Presence of Light: Divine Radiance and Religious Experience. Chicago: The University of Chicago Press. 336 pages.

Linnet, Jeppe T. 2011. Money Can't Buy Me Hygge: Danish Middle-Class Consumption, Egalitarianism and the Sanctity of Inner Space. Social Analysis. vol. 55, n 2, p. 21-44.

Lyon, Sarah \& Moberg, Mark (eds.). 2010. Fair Trade and Social Justice: Global Ethnographies. New York: NYU Press. 320 pages.

Merleau-Ponty, Maurice. 1964. Eye and Mind. In: Merleau-Ponty, M. \& Edie, James M. (ed.). The Primacy of Perception: and other Essays on Phenomenological Psychology, the Philosophy of Art, History and Politics. Evanston, IL.: North-Western University Press. p. 159-190.

Proctor, Robert \& Schiebinger, Londa L. (eds.). 2008. Agnotology: the Making and Unmaking of Ignorance. Stanford, Calif.: Stanford University Press. 312 pages.

Rauh, Andreas. 2012. Die bedondere Atmosphäre. Bielefeld: Transcript Verlag. 288 pages.

Schivelbusch, Wolfgang. 1988. Disenchanted Night: The Industrialization of Light in the Nineteenth Century. Berkely: The University of California Press. 227 pages.

Schmidt, Lars-Henrik \& Kristensen, Jens E. 1986. Lys, Luft of Renlighed. Den moderne social-hygiejnes fødsel. Viborg: Akademisk Forlag. 266 pages.

Shove, Elisabeth. 2003. Comfort, Cleanliness and Convenience: The Social Organization of Normality. Oxford: Berg. 224 pages.

Sloterdijk, Peter. 2011. Neither Sun nor Death. Los Angeles: Semiotext(e). 368 pages.

Stender, Marie. 2006. Om at bo i glashus, en antropologisk analyse af rum, synliggørelse og beboelsespraksisser $i$ københavnske boliger og arbejdspladser med transparent arkitektur, kandidatspeciale . København: Institut for Antropologi, Københavns Universitet. 112 pages.

Stewart, Kathleen. 2011. Atmospheric Attunements. Environment and Planning D: Society and Space. vol. 29, n 3, p. 445-453.

Sørensen, Natalia \& Haug, Peter N. (eds.). 2012. Nordic Light: Interpretations in Architecture. København: Dansk Center for Lys. 240 pages. 
Sørensen, Tim F. \& Bille, Mikkel. 2007. Lysets sociale afskygninger. Potentialer for et studium af lys, mørke og materiel kultur. Arkceologisk Forum. vol. 17, p. 28-32.

Verbeek, Peter-Paul. 2011. Moralizing Technology: Understanding and Designing the Morality of Things. Chicago: University Of Chicago Press. 200 pages.

Winther, Ida W. 2005. Hjemmet er mere end et hus. Jordens Folk. vol. 40, nº 2, p. 4-9.

Winther, Ida W. 2006. Hjemlighed. Kulturfeenomenologiske studier. København: Danmarks Pædagogiske Universitets Forlag. 284 pages.

Zumthor, Peter. 2006. Atmospheres. Berlin: Birkhäuser Verlag. 75 pages.

\section{NOTES}

1. This is a revised version of a paper given at the 2nd International Congress on Ambiances, in Montreal, September 2012, published in (Bille, 2012), and digitally on HALSHS. It also appears in a slightly revised form on www.sensorystudies.org. The author would like to thank Andreas Bandak and three anonymous reviewers for their comments.

2. My anthropological fieldwork in Copenhagen, Denmark, includes 60 qualitative interviews with adults in all ages and gender inhabiting both old and newly built apartments and houses.

3. http://www.seas-nve.dk/Privat/Energiraadgivning/Energispareraed/Belysning/ Goderaad.aspx. Consulted on May 27, 2013.

4. http://coopanalyse.dk/analyse/vi-elsker-stearinlys. Consulted on May 27, 2013.

5. http://ing.dk/artikel/89282-braendeovne-banker-dansk-partikelforurening-i-vejret. Consulted on May 27, 2013. It should be noted that statistics concerning particle pollution is heavily debated in Denmark.

\section{ABSTRACTS}

This article discusses the implementation of energy saving light bulbs in Denmark. It argues that such new climate technologies are part of an increasingly politicization of 'atmosphere' by linking the environmental imperative to decelerate impact on the earth's atmosphere with the everyday experiences of space through changes in visual expression. The article shows how enmity against new lighting technologies in Denmark is based on cultural notions and preferences towards shaping 'cosy spaces', and thereby offers insight into the social life of light. By focusing on the poor lighting quality of the energy saving light bulbs, the article shows how atmospheres are shaped by, and sometimes in contrast to, political ambitions.

Cet article traite de l'introduction des ampoules à économie d'énergie au Danemark. La promotion de technologies climatiques de ce type fait partie d'un processus de politisation des " atmosphères » qui conjugue l'impératif environnemental de réduire l'impact que nous avons sur notre planète avec nos expériences quotidiennes de l'espace, par le biais d'une modification 
de l'expression visuelle. Nous montrerons que la résistance danoise face aux nouvelles technologies d'éclairage est ancrée dans une préférence culturelle pour les espaces "intimes », dits «hyggelig» et nous fournit un moyen de mieux comprendre la vie sociale de la lumière. Partant de la mauvaise qualité des éclairages diffusés par les ampoules économiques, nous montrerons comment les atmosphères sont façonnées par, et parfois, contre les ambitions politiques.

INDEX

Keywords: atmosphere, light, candlelight, hygge, cosiness, Denmark, pollution, environment Mots-clés: ambiance, lumière, bougie, hygge, intimité, Danemark, pollution, environnement

\section{AUTHOR}

\section{MIKKEL BILLE}

Mikkel Bille is Assistant professor at the University of Copenhagen mbille@hum.ku.dk 